\title{
Policing in a Pandemic: a Commentary on Officer Well-being During COVID-19
}

\author{
Ann-Marie Edwards ${ }^{1}\left[\right.$ : Yasuhiro Kotera ${ }^{2}[$
}

Accepted: 2 July 2021 / Published online: 24 July 2021

(c) Society for Police and Criminal Psychology 2021

\begin{abstract}
The role of police officers during the coronavirus (COVID-19) pandemic is challenging, faced with the difficult task of keeping communities safe and preventing the spread of COVID-19 while putting their physical and mental health at risk. Emerging evidence points to the stress experiences of officers during the COVID-19 pandemic. With cases now surpassing 174 million and close to four million deaths worldwide, as well as stringent lockdown measures, police officers are faced with unprecedented challenges resulting from the pandemic. This commentary suggests police departments strengthen resources by putting in place appropriate emergency planning for future public health incidents, in addition to preparing for temporary or permanent loss of human resources. It is important to implement robust training plans post-pandemic to allow officers to offer better care for communities when faced with future public health emergencies. Finally, police officers should be provided with the resources and support to cope with the stresses associated with COVID-19.
\end{abstract}

Keywords Coronavirus $\cdot$ COVID-19 $\cdot$ Pandemic $\cdot$ Police mental health $\cdot$ Police leadership

\section{Introduction}

The novel coronavirus (COVID-19) was formally declared a global health pandemic by the World Health Organization (WHO) on 11 March 2020 (WHO 2020). Coronavirus has had a significant impact on the well-being of our communities and law enforcement agencies (LEA), who face unique challenges created by this global public health crisis (Frenkel et al. 2020; Stogner et al. 2020). These unprecedented health challenges (Laufs and Waseem 2020) will likely have a more significant impact on mental health than physical health (Kotera 2020), increasing the risk of anxiety, depression, and post-traumatic stress disorders (PTSD) (Greenberg 2020), which could result in a global mental health crisis post-pandemic (Kola 2020; Shuja et al. 2020). Survey data obtained from UK police, fire, and ambulance services reported an increase in mental health problems across the country's emergency services, with two in

Ann-Marie Edwards

annm.edwards@icloud.com

1 Graduate Student, University of Derby, Kedleston Road, Derby DE22 1GB, UK

2 Academic Lead, University of Derby, Kedleston Road, Derby DE22 1GB, UK five police officers reporting poor mental health since the start of the pandemic (Mind 2021). The rise in psychological illness could pose critical challenges for communities and law enforcement, with considerable and long-lasting consequences.

\section{Increased Risk of COVID-19 Infection}

Policing is widely recognized as a high-risk occupation, and compared to the general population, there is a greater risk of infection. The risk of infecting others has been reported as one of the primary causes of stress among officers during the pandemic (Frenkel et al. 2020), compounding the organizational stress already associated with the occupation (Stogner et al. 2020). Repeated exposure to these stressors is a cause for concern-challenges such as these place added pressure on officers. Moreover, policing is made even more difficult due to the lack of clear directives and inconsistent governmental measures (Frenkel et al. 2020; Sager and Mavrot 2020). The rise in the number of infected or COVID19-related fatalities in police officers is problematic. In many countries, police officers have been infected or died from contracting coronavirus while in the line of duty (National Law Enforcement Officers Memorial Fund 2020; Philippine National Police 2021). 
The role of a police officer has shifted since the start of the pandemic, from not only protecting our communities from crime but also playing a pivotal role in controlling the spread of the virus, maintaining public order, and promoting safer communities during the pandemic (Frenkel et al. 2020; Grover et al. 2020). Moreover, they increasingly encounter many COVID-19-related deaths (Fisher et al. 2020), repeatedly being called out to recover the bodies of the deceased (Grover et al. 2020; Laufs and Waseem 2020).

\section{Occupational Stressors of COVID-19}

Officer stress may become exacerbated due to increased workload and long working hours (Laufs and Waseem 2020). Police officers must be physically present within communities to carry out their role (Gordijn et al. 2017), sometimes in situations that could cause them physical and psychological harm. For example, many countries have seen large public demonstrations against coronavirus restrictions and the refusal of protesters to wear masks and socially distance puts officers at increased risk (Laufs and Waseem 2020). Police forces worldwide have had to adapt to new ways of working. The strain officers experience due to coronavirus is somewhat different from the usual occupational stresses of the job, primarily because of the perceived worry of virus exposure: in situations where there is the potential to become infected, and the constant fear of infecting others (Drew and Martin 2020; Grover et al. 2020). Not only that, but police stress and trauma have implications for others; it may harm relationships with their family and friends (Papazoglou and Tuttle 2018). These findings illustrate multi-dimensional stress experienced by officers.

The safest ways to protect each other from COVID-19 is social distancing and self-quarantining (Hansen and Lory 2020). However, community confidence in the handling of the COVID-19 pandemic is at an all-time low. As such, the police will be the first to encounter angry exchanges from the general public, who feel aggravated about the present situation, and stressed and worried about the possibility of infection. They have to adapt to the constant shift in restrictions, economic uncertainty, and isolation (Stogner et al. 2020). Relationships will need rebuilding once communities start to re-engage post-COVID, and we must address the subsequent mental health crisis that will emerge (Hansen and Lory 2020), not just for our communities but also for emergency service personnel. It is evident that a variety of factors significantly contribute to the development of mental ill-health in officers. We must therefore understand how this public health crisis impacts their psychological well-being.

\section{Policing Beyond COVID-19}

It is clear from previous research undertaken that a hypermasculine culture exists in the police force (Kurtz
2008; Silvestri 2017) — a culture that inhibits officers from seeking help (Edwards and Kotera 2020). As increased workload (Drew and Martin 2020) and the stress of possible virus exposure continue to be tackled by officers, departmental leadership should work to minimize the stress placed on officers as much as possible. One possible way would be to implement support initiatives that would mentally prepare officers for public health emergencies (Laufs and Waseem 2020).

There is evidence emerging on the stress experiences of officers during COVID-19 (Frenkel et al. 2020; Grover et al. 2020; Mehdizadeh and Kamkar 2020). A mixedmethod study by Frenkel et al. (2020) of officers from five European countries investigated police strain over three months following lockdown. Risk of infection, inadequate leadership, and communication emerged as the main stressors in this study. There were slight decreases in strain over time, with officers seemingly tolerating the pandemic. The findings obtained during Frenkel's study may have implications for understanding governmental, organizational, and individual coping strategies during pandemics.

It is addressing these problems through the implementation of effective public health emergency plans that need to be put in place by police forces, also, to establish precrisis preparation guidelines to improve the skills and competencies necessary in the future for officers to reduce mental health issues when similar public health emergencies arise (Laufs and Waseem 2020). There may be several waves or periods of public health emergencies in the future, undoubtedly affecting police departments on more than one occasion (McCurry 2020). It may be appropriate to be less reactive and introduce a more proactive planning approach to emergencies (Jefferson and Heneghan 2020). Adjustments to this degree also have implications for operational planning while ensuring the well-being of the workforce.

Coronavirus continues to spread rapidly (Kotera 2020). At the time of writing, cases surpassed 174 million worldwide (WHO 2021). Following the easing of initial lockdowns, stringent measures to deal with coronavirus outbreaks were reinstated in several countries. For example, the UK government imposed national and local lockdowns for several months to restrict movement. Worldwide vaccination programmes have been implemented. However, the effectiveness of such measures varies across countries. More recently, lockdowns, travel bans, and strict social distancing measures have been implemented to curb the spread of the virus in many countries, with such controls being enforced by the police (Laufs and Waseem 2020). The effect is the increased challenges and added stress faced by law enforcement officers (Mehdizadeh and Kamkar 2020). 
Table 1 Key recommendations for pandemic policing (integrated from Frenkel et al. 2020; Laufs and Waseem 2020); Milliard and Papazoglou 2020; Stogner et al. 2020)

Crisis management prepared- Put in place crisis and emergency management systems, plans, and processes at a governmental, organizational, ness and individual level.

Implement post-pandemic crisis intervention training.

Mental health Promoting resilience and improving mental health in police officers. Strengthen coping resources through additional training for police officers. Improve communication and stress-coping skills in officers.

Social support Design social support structures for police officers during operational duties while maintaining officer well-being.

\section{Critical Lessons Learned from COVID-19}

LEAs were most likely unprepared for the mental health impact of coronavirus on police officers (Stogner et al. 2020). For this reason, LEAs should identify and refer officers to mental health services to tackle the mental health burden imposed on them due to these continuing restrictions (Jetelina et al. 2020). For effective post-pandemic policing, a strong emphasis on community policing and crisis management training (Stogner et al. 2020) to identify the actions that need to be taken in the event of a public health crisis, will be necessary. Returning to pre-COVID operational levels will take time, but it is essential to start thinking about strengthening resources, being prepared, and improving police training. As suggested among Singaporean LEAs, preparatory measures such as training for psychological flexibility and technological skills may be helpful (Yap et al. 2020). Moreover, using the Operations Psychology Framework, clarifying the psychological and mental health issues at each dimension of operation (e.g. time, intervention, and command) may enhance their preparedness (Ang et al. 2011). Lessons learned from COVID-19 must be regularly revisited and corresponded to by continuous actions.

\section{How LEAs Are Responding to COVID-19}

While research on the impact of COVID-19 remains to be developed, suggested strategies for dealing with future public health incidents are based on comparative examples and lessons learned from previous emergencies (Chua et al. 2021; Laufs and Waseem 2020; McCanlies et al. 2018). Resources such as the American Society for EvidenceBased Policing (ASEBP) are a forum for sharing worldwide COVID-19 response strategies and policies for LEAs (The American Society of Evidence-Based Policing 2020). In Italy, the rural Carabinieri moved to the cities to patrol shops and cafes, while in Spain, the military has been called upon to support LEAs (The Brookings Institution 2021). Some LEAs in the USA have introduced police chaplains, who work closely with employee assistance programmes, counselling, and other departmental resources to support agency personnel and their families during the pandemic (Police
Executive Research Forum 2021). Others have suspended in-service training and roll call briefings to reduce the number of officers gathering indoors and to minimize the risk of infection; instead, virtual meetings were conducted wherever possible (Independent Office for Police Conduct 2020). In addition, limiting public access to police stations, face-toface interaction, and encouraging non-frontline staff to work from home have been implemented (The American Society of Evidence-Based Policing 2020). Lessons from disasters like Hurricane Katrina have implications for LEAs and provide important lessons and guidance on dealing with public health emergencies (Laufs and Waseem 2020). Preparing for temporary or permanent loss of human resources is critical to LEAs' ability to operate effectively during future public health emergencies (Sanberg and Mcfadden 2010). Discussions need to take place, and the effect of those measures needs to be evaluated.

\section{Conclusions}

The COVID-19 pandemic is likely to impact police departments around the world in many ways. There are several ways to approach such issues, some of which are highlighted in Table 1 (integrated from Frenkel et al. 2020; Laufs and Waseem 2020); Milliard and Papazoglou 2020; Stogner et al. 2020). First, current disaster plans should be revised initially, and in some cases, police departments will need to put in place effective emergency planning procedures. Second, the COVID-19 pandemic is likely to create unprecedented strains in resource and staff shortages, especially given how exposed police officers are and the challenges in maintaining social distancing measures in the field. Last, it is vital to provide officers with the tools and support through training to help them manage the pressures they face without risking their mental health while experiencing the stresses of the COVID-19 environment (Drew and Martin 2020).

Author Contribution AME wrote the message commentary. AME and YK revised the commentary. Both authors read and approved the final commentary. 


\section{Declarations}

Conflict of Interest The authors declare no competing interests.

\section{References}

Ang J, Diong SM, Misir C, Cheong J (2011) Operations psychology: the Singapore police experience. J Police Crim Psychol 26(2):69-76. https://doi.org/10.1007/s11896-010-9080-9

Chua AQ, Al Knawy B, Grant B, Legido-Quigley H, Lee WC, Leung GM, Looi MK, Maurer-Stroh S (2021) How the lessons of previous epidemics helped successful countries fight covid19. In The BMJ, Vol. 372. BMJ Publishing Group. https://doi. org/10.1136/bmj.n486

Drew JM, Martin S (2020) Mental health and well-being of police in a health pandemic: critical issues for police leaders in a postCOVID-19 environment. JCSWB 5(2):31-36. https://doi.org/10. 35502/jcswb. 133

Edwards AM, Kotera Y (2020) Mental health in the UK police force: a qualitative investigation into the stigma with mental illness. Int J Ment Heal Addict. https://doi.org/10.1007/ s11469-019-00214-x

Fisher EB, Miller SM, Evans M, Luu SL, Tang PY, Dreyer Valovcin D, Castellano C (2020) COVID-19, stress, trauma, and peer supportobservations from the field. Transl Behav Med 10(3):503-505. https://doi.org/10.1093/tbm/ibaa056

Frenkel MO, Giessing L, Egger-Lampl S, Hutter V, Oudejans RRD, Kleygrewe L, Jaspaert E, Plessner H (2020) The impact of the COVID-19 pandemic on European police officers: stress, demands, and coping resources. J Crim Just 101756. https://doi. org/10.1016/j.jcrimjus.2020.101756

Gordijn EH, Vacher L, Kuppens T (2017) "To serve and protect" when expecting to be seen negatively: the relation between police officers' contact with citizens, meta-stereotyping, and work-related well-being. J Community Appl Soc Psychol 27(3):253-268. https://doi.org/10.1002/casp.2310

Greenberg N (2020) Mental health of health-care workers in the COVID-19 era. Nat Rev Nephrol 16(8):425-426. https://doi.org/ 10.1038/s41581-020-0314-5

Grover S, Sahoo S, Dua D, Mehra A, Nehra R (2020) Psychological impact of COVID-19 duties during lockdown on police personnel and their perception about the behavior of the people: an exploratory study from India. Int J Ment Heal Addict. https://doi.org/10. 1007/s11469-020-00408-8

Hansen JA, Lory GL (2020) Rural victimization and policing during the COVID-19 pandemic. Am J Crim Justice 45(4):731-742. https://doi.org/10.1007/s12103-020-09554-0

Independent Office for Police Conduct (2020) Our response to the COVID-19 pandemic. Retrieved from https://www.policeconduct. gov.uk/our-response-covid-19-pandemic

Jefferston T, Heneghan C (2020). Covid 19 - Epidemic 'Waves.' Retrieved from https://www.cebm.net/covid-19/covid-19-epidemic-waves/

Jetelina KK, Molsberry RJ, Gonzalez JR, Beauchamp AM, Hall T (2020) Prevalence of mental illness and mental health care use among police officers. JAMA Netw Open 3(10):e2019658. https:// doi.org/10.1001/jamanetworkopen.2020.19658

Kola L (2020) Global mental health and COVID-19. In Lancet Psychiatry 7(8):655-657. Elsevier Ltd. https://doi.org/10.1016/S22150366(20)30235-2

Kotera Y (2020) Mental health in a pandemic. Professional Social Work 18. Retrieved from https://www.researchgate.net/ publication/344499675_Mental_health_in_a_pandemic

Kurtz DL (2008) Controlled burn: the gendering of stress and burnout in modern policing. Fem Criminol 3(3):216-238
Laufs J, Waseem Z (2020) Policing in pandemics: a systematic review and best practices for police response to COVID-19. Int J Disaster Risk Reduct 51(June):101812. https://doi.org/10.1016/j.ijdrr.2020.101812

McCanlies EC, Gu JK, Andrew ME, Violanti JM (2018) The effect of social support, gratitude, resilience and satisfaction with life on depressive symptoms among police officers following Hurricane Katrina. Int J Soc Psychiatry 64(1):63-72. https://doi.org/10.1177/0020764017746197

McCurry J (2020) Japan warns of third wave amid rising Covid infections. The Guardian. Retrieved from https://www.theguardian.com/world/ 2020/nov/11/japan-warns-of-third-wave-amid-rising-covid-infections

Mehdizadeh S, Kamkar K (2020) COVID-19 and the impact on police services. JCSWB 5(2):42-44. https://doi.org/10.35502/jcswb.139

Milliard B, Papazoglou K (2020) Another "brick in the wall" of police work: COVID-19. The important role of leadership to psychologically guide frontline law enforcement officers. Retrieved from https://www.blueline.ca/anotherbrick-in-the-wall-of-police-work-covid-19/

Mind (2021) Mind Cymru survey reveals toll of pandemic on ambulance workers' mental healthlmind, the mental health charity-help for mental health problems. Retrieved from https://www.mind. org.uk/news-campaigns/news/mind-cymru-survey-reveals-toll-ofpandemic-on-ambulance-workers-mental-health/

National Law Enforcement Officers Memorial Fund (2020) Law enforcement officers fatalities report. Retrieved from http:// nleomf.org/wp-content/uploads/2021/01/2020-LE-OfficersFatalities-Report-opt.pdf

Papazoglou K, Tuttle BMQ (2018) Fighting police trauma: practical approaches to addressing psychological needs of officers. SAGE Open. https://doi.org/10.1177/2158244018794794

Philippine National Police (2021) Covid-19 cases update as of May 14, 2021. Retrieved from https://pnp.gov.ph/index.php/news-andinformation/4024-pnp-covid-19-cases-update-as-of-decem ber-2-2020

Police Executive Research Forum (2021) COVID27Jan21. Retrieved from https://www.policeforum.org/covid27jan21

Sager F, Mavrot C (2020) Switzerland's COVID-19 policy response: consociational crisis management and neo-corporatist reopening. Eur Policy Anal 1-12. https://doi.org/10.1002/epa2.1094

Sanberg EL, Mcfadden SM (2010) Law enforcement preparedness for public health emergencies: an executive summary of the resources series. Retrieved from https://www.policeforum.org/assets/docs/ Free_Online_Documents/Public_Health/law enforcement preparedness for public health emergencies - an executive summary of the resources series 2010.pdf

Shuja KH, Aqeel M, Jaffar A, Ahmed A (2020) Covid-19 pandemic and impending global mental health implications. Psychiatr Danub 32(1):32-35. https://doi.org/10.24869/psyd.2020.32

Silvestri M (2017) Police culture and gender: revisiting the "cult of masculinity." Policing (oxford) 11(3):289-300. https://doi.org/10. 1093/police/paw052

Stogner J, Miller L, Mclean K (2020) Police stress, mental health, and resiliency during the COVID-19 pandemic. Am J Crim Justice 45(4):718-730

The American Society of Evidence-Based Policing (2020) ASEBP COVID-19 Police Portal. Law Enforcement COVID Portal. Retrieved from https://www.americansebpcovid.org/

The Brookings Institution (2021) How COVID-19 is changing law enforcement practices by police and by criminal groups. Retrieved from https://www.brookings.edu/blog/order-from-chaos/2020/ 04/07/how-covid-19-is-changing-law-enforcement-practices-bypolice-and-by-criminal-groups/

World Health Organization (2020) WHO Director-General's opening remarks at the media briefing on COVID-19 - 11 March 2020. Retrieved from https://www.who.int/dg/speeches/ detail/who-director-general-s-opening-remarks-at-the-mediabriefing-on-covid-19---11-march-2020 
World Health Organization (2021) WHO coronavirus disease (COVID19) dashboard. Retrieved from https://covid19. who.int/

Yap HL, Ho HF, Jansen Ang MZS, Danker TN, Tan YS, Zalzuli AD Force SP (2020) Supporting the police psychologically in a pandemic: the Singapore Experience. Crisis, Stress, and Human Resilience: Int J 2(1)
Publisher's Note Springer Nature remains neutral with regard to jurisdictional claims in published maps and institutional affiliations. 